\title{
AN ASSESSMENT OF COASTAL VULNERABILITY TO CLIMATE CHANGE IN SOUTH EAST QUEENSLAND, AUSTRALIA
}

\author{
Marcello Sano, Griffith Centre for Coastal Management and Griffith Climate Change \\ Response Programme, Griffith University, Australia m.sano@griffith.edu.au \\ Scott Baum, Urban Research Program and Griffith Climate Change Response Programme, \\ Griffith University, Australia s.baum@griffith.edu.au \\ Florence Crick, Urban Research Program and Griffith Climate Change Response \\ Programme, Griffith University, Griffith University, Australia f.crick@griffith.edu.au \\ Darryl Low Choy, Urban Research Program and Griffith Climate Change Response \\ Programme, Griffith University, Griffith University, Australia d.lowchoy@griffith.edu.au \\ Silvia Serrao-Neumann Urban Research Program and Griffith Climate Change Response \\ Programme, Griffith University, Griffith University, Australia \\ s.serrao-neumann@griffith.edu.au \\ Rodger Tomlinson, Griffith Centre for Coastal Management and Griffith Climate Change \\ Response Programme, Griffith University, Griffith University, Australia \\ r.tomlinson@griffith.edu.au
}

\begin{abstract}
South East Queensland, one of the fastest growing regions in Australia, is highly exposed to the impact of climate change, especially on the coast. This paper explores the vulnerability of the coastal system as part of a wider regional system. This is carried out using an integrated approach combining quantitative indicators of exposure, sensitivity and adaptive capacity, spatially represented at the suburb level, and an analysis of the management system. The results include an assessment of the spatial vulnerability of the system and its implications to coastal management, to be used as a platform for discussion with stakeholders and decision makers at local and regional levels.
\end{abstract}

Keywords: Integrated Coastal Zone Management, vulnerability assessment, climate change adaptation, South East Queensland, Australia

\section{Introduction}

South East Queensland (SEQ) is one of the most developed and fastest growing coastal regions in Australia. This trend is set to continue as its population, currently around 2.8 million people, is expected to grow by $60 \%$ in the next 20 years (Department of Infrastructure and Planning 2009). The high concentration of population within the low-lying coastal zone (figure 1) has prompted the IPPC in its Fourth Assessment Report to explicitly identify the coastal SEQ region as highly vulnerable to the impacts of climate change (Hennessy et al 2007). Specifically SEQ coastal settlements, distributed across 5 coastal councils (Sunshine Coast Regional Council, Moreton Bay Regional Council, Brisbane City Council, Redland City Council, Gold Coast City Council), are extremely vulnerable to sea-level rise (SLR), changing wave climate and extreme sea levels associated with storm tides. Current coastal erosion, inundation and recession can be exacerbated by a combination of these processes. 


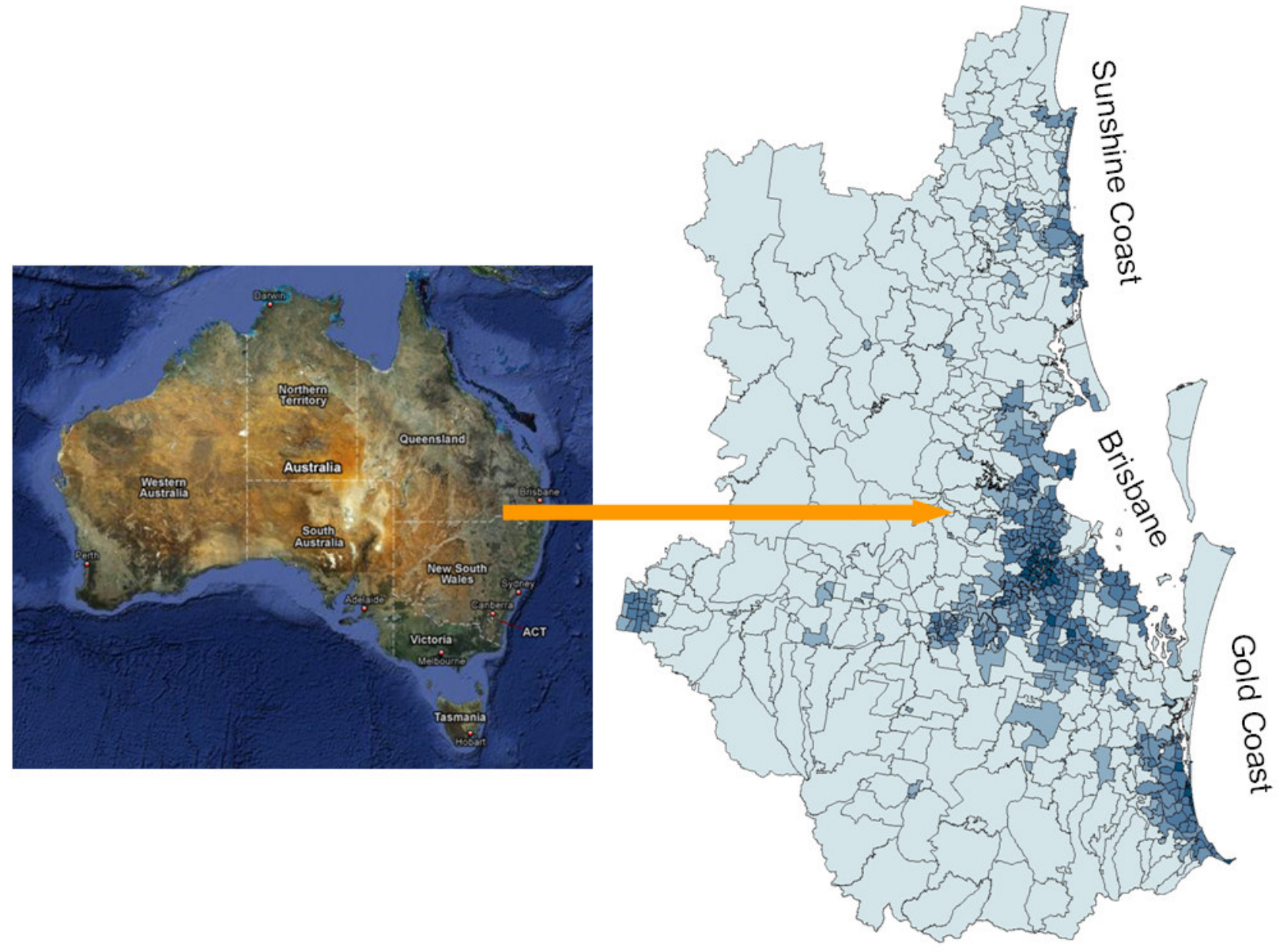

Fig. 1. South East Queensland region with population density.

The SEQ coastal zone, from the northern boundary of the Sunshine Coast to the Queensland-New South Wales border, has a linear extension of around $280 \mathrm{~km}$. A detailed analysis of the shoreline using a recent Australian coastal geomorphic map "Smartline" shows around $500 \mathrm{~km}$ of moderate to highly exposed sandy shores and a total extension of around $1,800 \mathrm{~km}$ of shore exposed to changing sea levels, including bays, inlets and estuaries. Most of these shores have been modified by development, including training walls, groynes, seawalls and canals.

While global mean sea level has risen at a rate of about $1.7 \mathrm{~mm}$ per year in the last two centuries, in Australia figures are slightly lower as sea level rose about $1.2 \mathrm{~mm}$ per year (Church et al 2008). For SEQ, this figure was $1.3 \mathrm{~mm}$ during the period 1990-2008 (NTC BOM 2008). Current projections based on the IPCC AR4 suggest a global worst case scenario SLR of around $60 \mathrm{~cm}$ by 2100 (IPCC 2007), but in eastern Australia, the influence of a warming East Australian Current moving further south makes the SLR projections greater than the global level (Department of Climate Change 2009). Regional projections, combining the figures of the IPCC AR4 with regional variations from the global averages, 
have been recently provided (CSIRO 2009) resulting in a SLR for SEQ of around $80 \mathrm{~cm}$ by 2100, adopted by the State government as a reference figure (Department of Environment and Resource Management 2009).

SLR is not the only impact of a changing climate, which may affect also average wave conditions and extreme events. In SEQ the average wave climate, the frequency of extreme events and consequently the transport of sediments and ultimately the shape of the coast are mainly driven by two types of storms: tropical cyclones and east coast lows. While fluctuations of the present wave climate have been analysed and recorded (Hemer et al. 2008), projections of future wave climate are still uncertain and are currently under investigation (Abbs 2009, Hemer et al. 2009).

SLR and changing patterns in the wave climate and extreme storms can exacerbate the already complex issue of managing human settlements and infrastructure on dynamic environments. The coastal management framework applicable to the SEQ region includes a range of policies, plans and schemes issued by the various tiers of government. While the federal government offers limited guidance to the States in the implementation of their coastal policies, the Queensland Government has the responsibility for natural resource management and statutory land use planning, including coastal zone management. Local councils are responsible for integrating state coastal policies into local government instruments, such as planning schemes and shoreline management plans.

The integration of climate change projections into the coastal management framework remains a key challenge. This is largely the result of uncertainties surrounding projections and the lack of statutory obligations. At present, only a limited number of aspects of climate change have been considered in coastal plans and policies, at federal, state, regional and local level. For example, SLR projections are provided by the Queensland Government, based on the most robust science available, but wave climate patterns have largely been neglected or are too general, due to the uncertainties in future projections.

This research aims to address this challenge as part of the South East Queensland Climate Adaptation Research Initiative (SEQ-CARI) - Human Settlements component, a three-year cross-sectoral project covering urban planning and management, including coastal management, emergency management and human health. The Initiative will develop and improve the adaptation strategies, policies, and practices in each sector and across sectors, for better governance and management in response to the impacts of climate change. This paper focuses on the first output of the Initiative, namely a regional vulnerability assessment, particularly related to the coastal component. The regional vulnerability study provides a starting point for discussion and interaction with stakeholders from specific local government areas which will generate insights to build scenarios for future adaptation.

With this in mind, the aims of this paper are to: (i) present SEQ as a case study of a highly vulnerable coastal area; (ii) propose a methodological framework to assess spatial vulnerability and the implications to the coastal management system; and (iii) present the preliminary results of this study to discuss adaptation options within coastal settlements.

The first section of the paper focuses on the current literature and trends in vulnerability assessments. The second section synthesizes the methodological approach used to analyze the system, focusing on the coastal component, while the results are then presented in the third section. 


\section{Current trends in vulnerability assessments}

Few coastal vulnerability and risk studies currently available in the scientific literature provide effective techniques that enable the transfer of outputs from an integrated vulnerability approach (i.e. one that incorporates biophysical as well as social components of vulnerability) into policy formulation and implementation. Most of the studies focus on assessing coastal vulnerability based on physical variables, paying less attention to the social, economic and governance components of the system (Abuodha \& Woodroffe 2006; Tol et al 2008). In addition, these vulnerability assessments focus mainly on the impact of SLR or climate variability on the present without considering non-climatic changes in coastal areas, which have characterized the last decades and are likely to continue in the future (Nicholls et al 2008). In order to produce assessments that can yield a greater contribution to policy development, particularly related to climate change adaptation, there are calls for new types of vulnerability studies to take place (Kelly and Adger 2000; Burton et al 2002). Ultimately, these studies have to assist in mapping potential hot spots and identifying major drivers to effectively contribute to policy formulation (Eriksen \& Kelly 2007).

Although there is a large debate surrounding the concept of vulnerability itself, there is growing consensus in terms of the components of vulnerability (Nelson et al 2010). In this context, this study adopts the definition of vulnerability and its components - exposure, sensitivity and adaptive capacity - proposed by the IPCC AR4. Thus, vulnerability is understood here as a function of the character, magnitude, and rate of climate change and variation to which a system is exposed, its sensitivity, and its adaptive capacity (IPCC 2007).

In this definition, (i) exposure refers to the expected changes to climatic stimuli in a given location. For example, coastal regions are exposed to SLR and other climate change-driven changes in coastal processes. (ii) Sensitivity is the degree to which a system may directly or indirectly be affected by climate variability or change. For example, the sensitivity of low lying and sandy coastal regions to SLR is much higher than for a rocky coastline. Together, exposure and sensitivity produce the potential impacts of climate change, which can be attenuated by the individual or system's adaptive capacity. (iii) Adaptive capacity refers to the ability or potential to respond successfully to climate variability and change, including adjustments in behaviour, resources and technologies.

\section{Methodological approach for the coastal vulnerability assessment}

The methodological approach proposed by this paper integrates (i) a spatial vulnerability assessment of the coastal region and (ii) an assessment of the vulnerability of the coastal management system.

\subsection{Spatial vulnerability assessment}

The approach followed for the spatial vulnerability assessment is informed by that used by Baum et al (2009) and based on the spatial representation of indicators of exposure, sensitivity and adaptive capacity of the coastal region, using suburbs as the spatial unit for representation, and their combination using a vulnerability index. The selection of appropriate indicators for each of these components was informed by the existing literature on vulnerability assessment and mapping, in particular the earlier work undertaken by Preston et al (2008). 
Exposure. A complete vulnerability assessment should cover a wide range of exposure data, including regional sea level projections, wave climate and future extreme events projections. Given that such detailed data is yet to be produced for the region, this study computed the exposure indicator by combining the latest SLR projection for SEQ $(80 \mathrm{~cm}$ by 2100) with existing records of the highest astronomical tide , averaged at the suburb level.

Sensitivity. The Smartline Dataset (Sharples et al 2009), providing information on coastal geomorphology, is used as an indicator of the sensitivity of shoreline segments to the oceanic swell and storm wave energy based on coastal landforms, its topography and lithology. The combination of the Smartline information with population sensitivity information in the coastal suburbs provides an average sensitivity of each suburb.

Adaptive capacity. Adaptive capacity indicators used in previous vulnerability assessments and mapping studies include both demographic and socio-economic data (e.g. Cutter et al 2003). As such, a selection of adaptive capacity indicators based on available census data at the suburb level was used.

The complete list of indicators of exposure, sensitivity and adaptive capacity is reported in table 1.

\begin{tabular}{|c|c|c|}
\hline \multicolumn{3}{|c|}{ Coastal vulnerability } \\
\hline Exposure & Sensitivity & Adaptive capacity \\
\hline \multirow[t]{2}{*}{$\begin{array}{l}\text { 1. Impact of future } \\
\text { extreme sea level } \\
\text { ('Bathtub' on } 1 \mathrm{~m} \\
\text { Digital Elevation } \\
\text { Model) }\end{array}$} & $\begin{array}{l}\text { 1. geomorphologic } \\
\text { sensitivity (Smartline } \\
\text { dataset) }\end{array}$ & $\begin{array}{ll}\text { 1. } & \text { population } \\
\text { completing high } \\
\text { school (Australian } \\
\text { Bureau of Statistics) }\end{array}$ \\
\hline & $\begin{array}{ll}\text { 2. } \% \text { population } \geq 65 \\
\text { years of age } \\
\text { (Australian Bureau of } \\
\text { Statistics) } \\
\text { 3. } \% \text { population } \geq 65 \\
\text { years of age \& living } \\
\text { alone (Australian } \\
\text { Bureau of Statistics } \\
\text { 4. } \% \text { population } \leq 4 \\
\text { years of age } \\
\text { (Australian Bureau of } \\
\text { Statistics) }\end{array}$ & 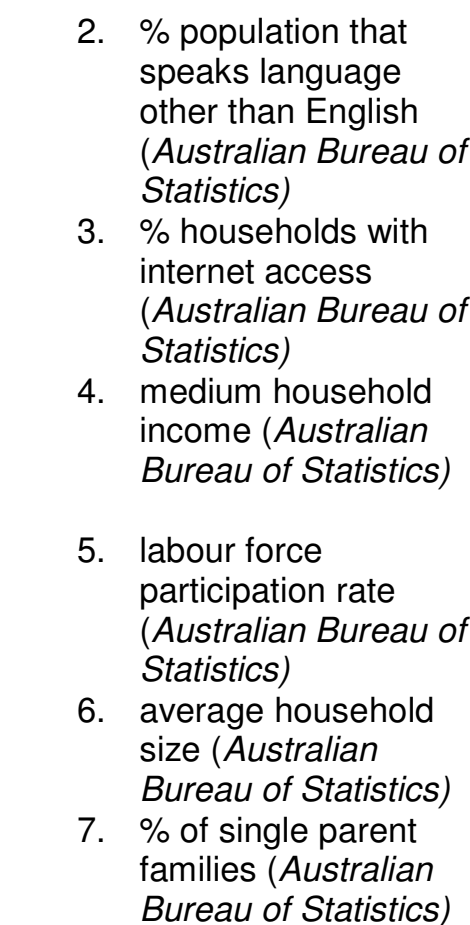 \\
\hline
\end{tabular}




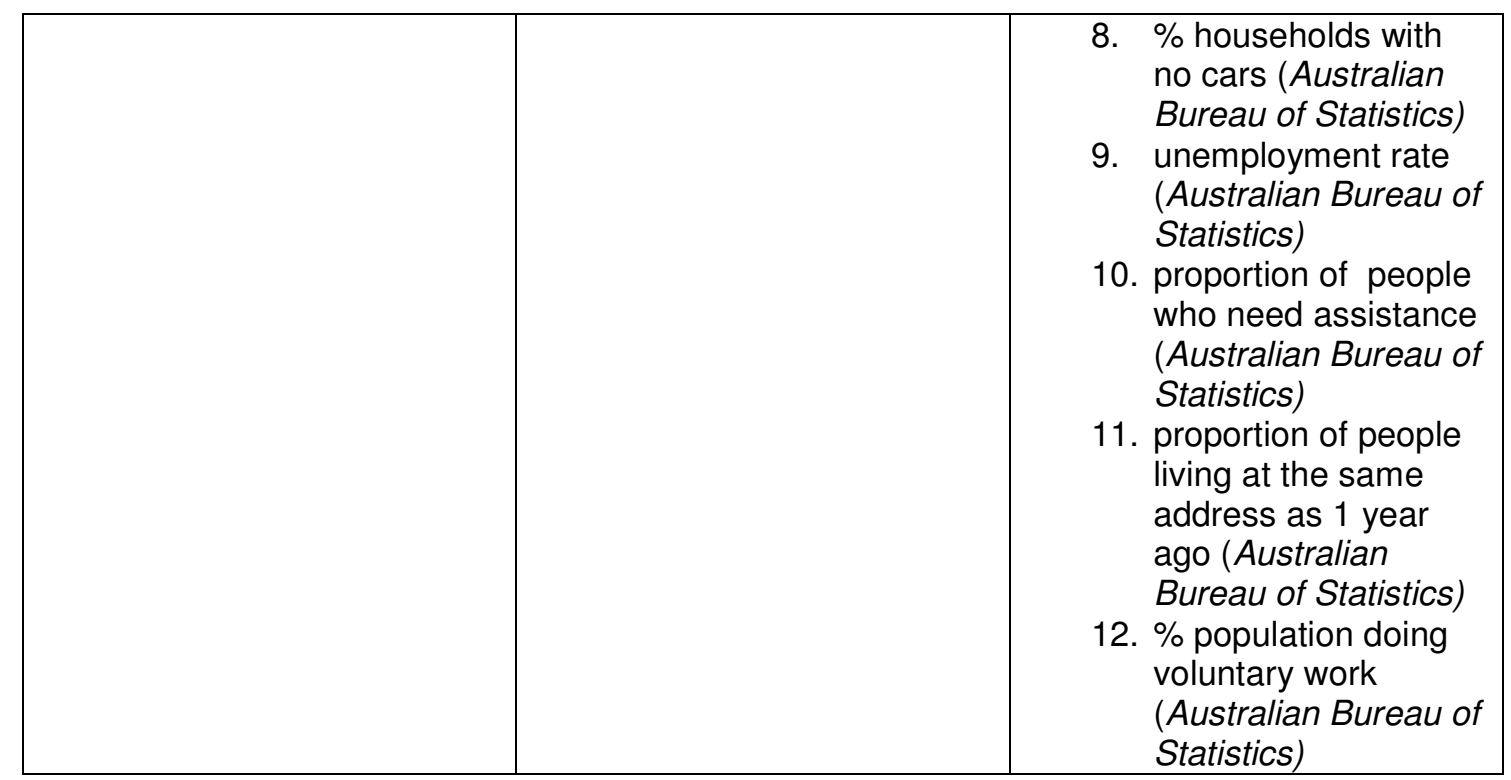

Tab 1. Indicators of exposure (E), sensitivity (S) and adaptive capacity $(A)$ used for the calculation of the overall vulnerability $(V)$ for the $S E Q$ region.

The individual measures of exposure, sensitivity and adaptive capacity were constructed using a simple additive process whereby each individual variable was first standardised and then all components were added together. The adopted method of index development is based on Langlois and Kitchen (2001) and re-proposed by Baum (2004 and 2008); where vulnerability in suburb $i\left(V_{i}\right)$ depends on:

$$
V_{i}=\frac{E_{i} *\left(1+S_{i}+A_{i}\right)}{n}
$$

Where:

$E_{i}$ the exposure for suburb $i$;

$S_{i}$ the sensitivity for suburb $i$;

$A_{i}$ the adaptive capacity for suburb $i$; and

$n$ the total number of components included in the index.

Results can be depicted by maps of exposure, sensitivity and adaptive capacity of coastal suburbs, and a net coastal vulnerability map combining all three components.

\subsection{Sectoral vulnerability assessment}

The spatial vulnerability assessment is complemented by an assessment of vulnerabilities related to the current policy domain of the coastal management sector. The assessment investigates current tools, strategies, models and mechanisms adopted by the coastal management sector that directly influence management practices as well as future climate change adaptation options. The approach adopted in this study explores the coastal 
management system and addresses (i) the current sectoral practices affecting the region (in the light of the current knowledge) and (ii) the implications of the spatial vulnerability assessment to coastal management.

Further investigation will be developed using an integrated approach to: (i) model and analyze the coastal management systems; (ii) assess their level of adaptation; and (iii) address the identification of adaptation options (Sanò et al. 2010).

\section{Results}

The maps, showing the results of the spatial vulnerability assessment, represent sensitive information which could not be disclosed at this stage of the project. However, some general comments on the results are the following:

The exposure maps highlights that all five coastal councils exhibit some level of exposure to coastal hazards. The bulk of high exposure to coastal hazards is within the Gold Coast area, but there are also areas with extremely high exposure along the coastal suburbs of Brisbane, Moreton Bay and Sunshine Coast.

The sensitivity map shows that most of the SEQ coastal suburbs are extremely sensitive sedimentary environments which can be affected by SLR and hydrodynamic changes. This geomorphological sensitivity is further compounded by the high density of the population and presence of major infrastructure located within close proximity to the coastline.

Whilst the entire coastline is considered to have extremely high sensitivity to coastal hazards, it is important to note that the five coastal councils have considerable capacity to deal with coastal hazards, with most being of notably medium to high levels of adaptive capacity, Although there are pockets of low adaptive capacity.

Concerning the final vulnerability spatial information, it is not surprising that low lying and growing suburbs, especially in the Gold Coast and the Sunshine coast, are the most vulnerable to coastal hazards and coastal impacts of climate change across the region.

However, the vulnerability of SEQ's coast is due to both the spatial features of the region (low lying highly developed suburbs) and climate change risks on the current coastal planning and management system ranging from the federal level to the local level. The integration of climate change policies into coastal management practice at the state level has been a slow process, particularly due to the limited guidance provided by the Federal Government in addressing this specific issue at the national level. Despite this, the Queensland Government is reviewing its coastal planning and management framework to include the challenges posed by climate change, such as SLR and increasing cyclone intensity. However, the most critical position is occupied by coastal local governments who face complex day-to-day decisions both when preparing climate change-adapted planning schemes and when assessing new development proposals. Changes in climate figures and the uncertainties in climate projections are likely to exacerbate management issues in the future and increase the challenges that local governments have to address in coastal management. 


\section{Conclusions}

The aim of this paper was to present the SEQ coastal region as a highly vulnerable area to the impact of climate change, provide a methodological framework to assess its vulnerability and present some preliminary results.

This information will be used to inform a stakeholder engagement process aiming at the construction of scenarios for future adaptation.

Despite the limitations of using an indicator-based spatial analysis to generate recommendations addressing socio-economic issues, it is clear that the majority of the coastal region is intrinsically highly exposed and sensitive to climatic drivers, and the reduction of vulnerability should primarily be addressed through improvements in adaptive capacity and identification of sustainable adaptation options. The coastal management system is highly influenced by the current political climate rather than future climatic changes. Nevertheless, current policies are attempting to incorporate climate projections and current results, especially at the state level, can be considered satisfactory. Major issues are perhaps the role of the federal government in addressing climate change adaptation and the practical responses of local councils in a context of uncertainty and changing climate projections. This may require flexible mechanisms to incorporate new SLR and wave climate figures into coastal plans and shoreline erosion management plans. New concepts will need to be integrated into local planning schemes such as dynamical buffer zones capable of accommodating worst case scenarios with overall lower costs for the society in the long term. In addition, uncertainties surrounding climate projections call for an adaptive management process that is able to amend planning and management options as new science and information become available.

\section{References}

Abbs, D. 2009, Downscaling Tropical Cyclones for Climate Change Studies for the Australian Region, Personal Communication, CAWCR Modelling Workshop 2009: Modelling \& Understanding High Impact Weather.

Abuodha P. \& Woodroffe C. 2006, International assessments of the vulnerability of the coastal zone to climate change, including an Australian perspective, Australian Greenhouse Office, Department of the Environment and Heritage.

Baum, S. 2004, 'Measuring socio-economic outcomes in Sydney: an analysis of census data using a general deprivation index', Australasian Journal of Regional Studies, Vol. 10, pp. 105- 133.

Baum, S. 2008, Suburban Scars: Australian Cities and Socio-economic Deprivation, Urban Research Program, Research Paper 15, Griffith University, Brisbane.

Baum, S., Horton, S., Low Choy, D. \& Gleeson, B. 2009, Climate change, health impacts and urban adaptability: case study of Gold Coast City, Research Monograph 11, Urban Research Program, Griffith University (online), Available: http://www.griffith.edu.au/_data/assets/pdf_ file/0011/119864/urp-rm11-baum-et-al-2009.pdf (20 May 2010).

Burton, I., Huq, S., Lim, B., Pilifosova, O. \& Schipper, E. L. 2002, 'From impacts assessment to adaptation priorities: the shaping of adaptation policy', Climate Policy, vol.2, pp. 145-159. 
Bussey M., Carter, R., Carter, J., Mangoyana, R., Matthews, J., Nash, D., Oliver, J., Richards, R., Thomsen, D., Sano, M., Smith, T. \& Weber, E. 2010, Historical Scenarios as a Tool of Anticipatory Action Learning: Climate Adaptation, Futures Thinking, and Historical Memory, Proceedings from IFSAM 2010 Justice and Sustainability in the Global Economy, Paris July 8th to the 10th.

Church, J., White, N., Hunter, J., McInnes, K., Cowell, P. \& O'Farrell, S. 2008, 'Sea-level rise', in Transitions: pathways towards sustainable urban development in Australia, ed. P. Newton, CSIRO Publishing, Melbourne.

CSIRO 2010, Sea Level Rise. Projections for the Australian Region (online), Available: http:// www.cmar.csiro.au/sealevel/sl_proj_regional.html (20 May 2010).

Cutter, S. 2003, 'The Vulnerability of Science and the Science of Vulnerability', Annals of the Association of American Geographers, vol. 93, pp. 1-12.

Department of Climate Change 2009, Climate Change Risks to Australia's Coast. A first Pass National Assessment, Australia Government.

Department of Environment and Resource Management 2009, Draft Queensland Coastal Plan. Explanatory Notes, Department of Environment and Resource Management, Queensland Government.

Department of Infrastructure and Planning 2009, South East Queensland Regional Plan 2009- 2031, Brisbane, The State of Queensland.

Eriksen, S. \& Kelly, P. 2007, 'Developing Credible Vulnerability Indicators for Climate Adaptation Policy Assessment', Mitigation and Adaptation Strategies for Global Change, vol. 12, pp. 495- 524.

Hemer, M., Mclnnes, K., Church, J. , O'Grady , J. \& Hunter, J. 2008, Variability and trends in the Australian wave climate and consequent coastal vulnerability, CSIRO Final Report for Department of Climate Change.

Hemer, M. , Mclnnes, K. \& Ranasinghe, R. 2009, Future Projections of the East Australian Wave climate, Proceedings of the 11th International Workshop on wave hindcasting and forecasting and coastal hazards, Halifax, Canada.

Hennessy, K., B. Fitzharris, B.C. Bates, N. Harvey, S.M. Howden, L. Hughes, J. Salinger and R. Warrick, 2007: Australia and New Zealand. Climate Change 2007: Impacts, Adaptation and Vulnerability. Contribution of Working Group II to the Fourth Assessment Report of the Intergovernmental Panel on Climate Change, M.L. Parry, O.F. Canziani, J.P. Palutikof, P.J. van der Linden and C.E. Hanson, Eds., Cambridge University Press, Cambridge, UK, 507-540.

IPCC 2007, Climate Change 2007: Impacts, Adaptation and Vulnerability. Contribution of Working Group II to the Fourth Assessment Report of the Intergovernmental Panel on Climate Change, eds. M. Parry, O.Canziani, J. Palutikof, P.van der Linden \& C. Hanson, Cambridge University Press, Cambridge, UK, 976pp.

Kelly, P. \& Adger, W. 2000, 'Theory and practice in assessing vulnerability to climate change and facilitating adaptation', Climatic Change, vol.47, pp. 325-352.

Langlois, A. \& Kitchen, P. 2001, 'Identifying and measuring dimensions of urban deprivation in Montreal: An analysis of the 1996 census data', Urban Studies, vol. 38, pp. 119-139.

Nelson, R., Kokic, P., Crimp, S., Meinke, H. \& Howden, S. 2010, 'The vulnerability of Australian rural communities to climate variability and change: Part I-Conceptualising and measuring vulnerability', 
Environmental Science \& Policy, vol. 13, pp. 8-17.

Nicholls R., Wong, P., Burkett, V., Woodroffe, C. \& Hay, J. 2008, 'Climate change and coastal vulnerability assessment: scenarios for integrated assessment', Sustainability Science, Vol. 3, pp. 89102.

NTC BOM 2008, The Australian Baseline Sea Level Monitoring Project, Annual Sea Level Data Summary Report, July 2007 - June 2008.

Preston, B., Smith, T., Brooke, T., Gorddard, R., Measham, T., Withycomber, G., Mclnnes, K., Abbs, D., Beveridge, B. \& Morrison, C. 2008, Mapping Climate Change Vulnerability in the Sydney Coastal Councils Group, Prepared for the Sydney Coastal Councils Group.

Sanò M., Mustelin J., Lazarow N., Tomlinson R. 2010. Adapting coastal policies and instruments to climate change: a case study from South East Queensland, Australia. 2010 Climate Adaptation Futures Conference. Gold Coast, Australia, 29/06 to 01/07 2010. National Climate Change Adaptation Research Facility \& Climate Adaptation Flagship CSIRO.

Sharples, C., Mount, R. \& Pedersen, T. 2009, The Australian Coastal Smartline Geomorphic And Stability Map Version 1: Manual And Data Dictionary, Report of the University of Tasmania for the Department of Climate Change and Geoscience Australia.

Tol, R., Klein, R. \& Nicholls, R. 2008, 'Towards Successful Adaptation to Sea-Level Rise along Europe's Coasts', Journal of Coastal Research, Vol. 24, pp. 432-442.

\section{Acknowledgements}

This research is part of the South East Queensland Climate Adaptation Research Initiative, a partnership between the Queensland and Australian Governments, the CSIRO Climate Adaptation National Research Flagship, Griffith University, University of the Sunshine Coast and University of Queensland. The Initiative aims to provide research knowledge to enable the region to adapt and prepare for the impacts of climate change. Authors gratefully acknowledge the financial support provided by Griffith Climate Change Response Programme to attend the Littoral 2010 conference in London, UK. 